\title{
DISCUSSION
}

\section{Failure mechanism of the Aznalcóllar Dam, Seville, Spain.}

\author{
C. OLALLA and V. CUÉllaR (2001). Géotechnique 51, No. 5, 399-406
}

Dr A. D. M. Penman, Chairman ICOLD Committee on Tailings Dams and Waste Lagoons

A major difference between embankment dams built to retain water and tailings dams, is their rate of construction. The Aznalcóllar dam was designed to retain water into which tailings were to be placed with a view to keeping the material wet to minimise oxidation and the formation of acid. Had it been built to its full height at one time, it might have looked like the design ideal shown by Fig. 1 of the paper. In fact, in common with most tailings dams, it was constructed in stages, as shown by Fig. 18, over a period of 20 years, raised only to keep pace with the rising level of tailings in the impoundment.

The starter dam and the bentonite-cement diaphragm cutoff wall were constructed at the beginning of the project, and the first part of the sloping impervious core with backup filters and compacted waste rockfill built during the following few years to correct upstream and downstream slopes. Later and up to nearly the end of 1988 , construction became more irregular, and it is not clear that the integrity of the impervious core was maintained. A considerable amount of waste rockfill was placed between 1988 and 1990, greatly increasing the width of the dam. During the last eight years prior to failure, the rate of height increase was quite slow.

Leakage measured as $100 \mathrm{~m}^{3} / \mathrm{h}$ was flowing to the river and during 1995 some grouting was carried out from the dam crest. Water was seen to be issuing from the downstream slope at about quarter height. A line of 42 relief wells was placed between the dam toe and the river towards the end of 1997. They were $2 \mathrm{~m}$ diameter, spaced at about every $25 \mathrm{~m}$. Excavation went down through the alluvium and at least $1 \mathrm{~m}$ into the marl, and the wells were backfilled with a selected sand and gravel. Some were interconnected by thrust boring so that it was not necessary to have a sub- mergible pump in every well. Water pumped from them amounted to $1000 \mathrm{~m}^{3} / \mathrm{h}$.

In 1996 the impoundment was subject to a full-scale stability study by independent experts and the Spanish authorities. No signs of instability were detected at that time; however, it continued to be subject to regular thirdparty inspections, the last less than two weeks before the failure. Had there been concern about the stability of the dams?

It is unfortunate that the failure occurred during the hours of darkness so that there were no witnesses, but there is some evidence to suggest that the main dam failed north of the dividing dam, prior to the bodily movement of the main dam adjacent to and south of the dividing dam, on a shear plane deep in the marl. In addition to the physical conditions at the breach, river flow measurements showed two peaks, one at $03 \cdot 25$ hours with a second at $08 \cdot 30$, indicating that failure occurred in two stages.

The discusser agrees with the Authors' conclusions that the large movements that occurred on a near horizontal feature deep in the marl were due to a combination of progressive failure assisted by high pore pressures possibly migrating under the dam and its downstream unloaded toe from the area under the very heavy tailings impoundment. However, do they think that the triggering mechanism could have been movement of the dam north of the dividing dam due to the evidently very high phreatic surface and seepage of water through the dam? Slight movement could be sufficient to induce liquefaction of the tailings that, with their bulk density of $28 \mathrm{kN} / \mathrm{m}^{3}$, could increase horizontal thrust against the dam.

As stated in our current ICOLD Bulletin No. 121, in which this case is one of 221 case records of tailings dam incidents, several eminent geotechnical engineers have

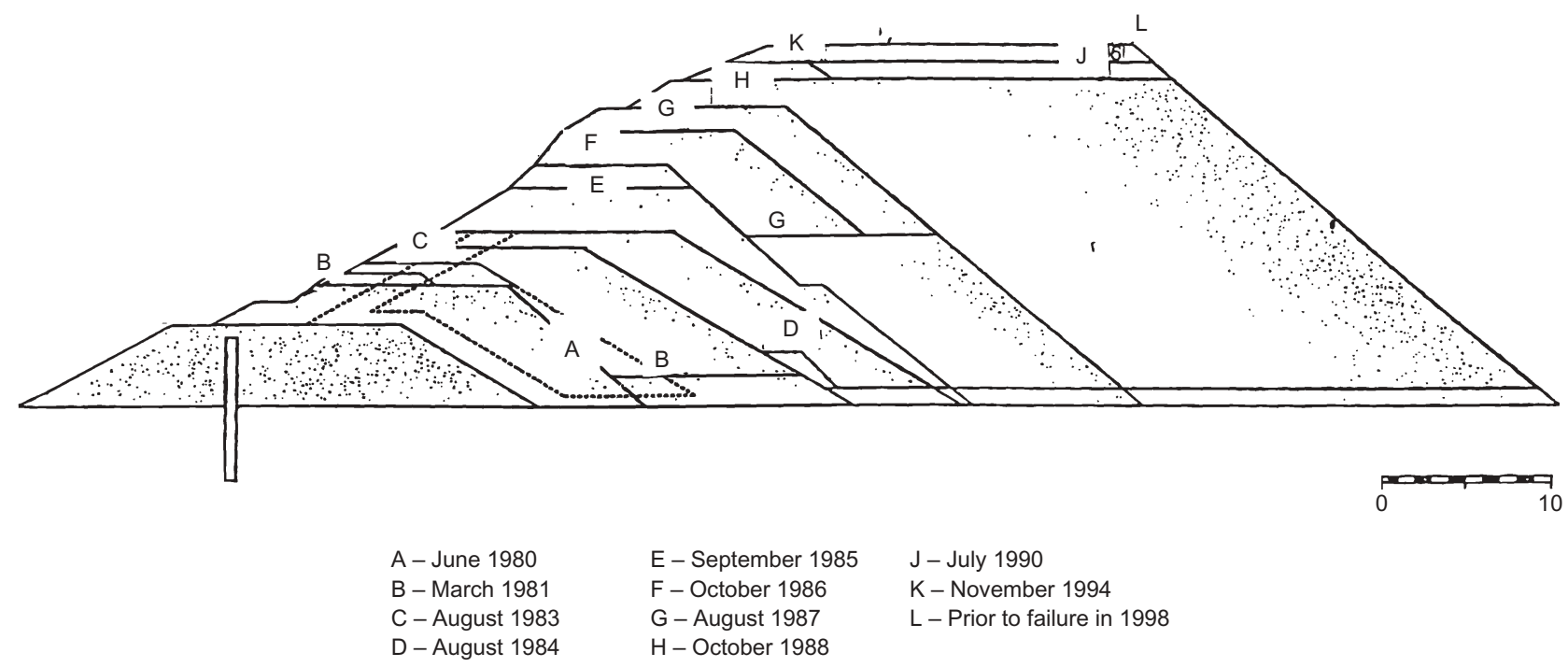

Fig. 18. Construction sequence of Aznalcóllar Dam 
expressed the view that such behaviour would have been extremely difficult to predict.

\section{Authors' reply}

We appreciate very much the discussion submitted by Dr Penman, which will contribute to a better understanding of this event. However, we should like to make some comments on his interesting contribution.

One of the biggest concerns during the study of the failure mechanism was the influence of large amounts of leakage of extremely acid water $(\mathrm{pH}=3)$. Several features, such as the observation of particles of tailings that have migrated through the alluvium gravels and cementation of the river alluvium at some points of the dam foundation, have been provided in the full study (CEDEX, 1998) to demonstrate that, probably over a long period of time, water flowed through the permeable alluvium, despite the presence of a slurry cut-off trench. Concerning Dr Penman's opinions that 'it is not clear that the integrity of the impervious core was maintained', or 'water was seen to be issuing from the downstream slope at about quarter height', we have not found evidence to support them. On the contrary, the high permeability observed in the rockfill of the dam's shoulder makes it difficult to imagine that possibility. Full-scale stability studies were undertaken in 1978 and in 1996 by competent geotechnical firms using the Morgenstern and Price, and Carter methods respectively. We do not know, specifically, that the Spanish authorities could have been involved directly in the execution of this kind of study. Spanish authorities were not directly engaged in these types of analysis. Spanish law regulates the management of these types of private dam, and an intense monitoring system was implemented and was periodically analysed by a competent and independent Spanish private company, as one of the precautions against such emergencies. The dam had been inspected some days before the slide, and no signs of external anomalies were observed. Consequently, the stability of the dam was not a matter of concern.

The river flow measurements, which are automatically registered some kilometres below the site at Guardamar River, showed two peaks during the night of the failure. Different explanations may be provided to explain this observation. Our opinion is that a wave of free water arrived first, and then, some $3 \mathrm{~h}$ later, a second wave consisting mainly of tailings arrived.

Different mechanisms of failure of the dam body have been suggested by the different parties involved in the dam failure, even different from Dr Penman's point of view, to justify the existence of these two peaks. In this sense, we do not think that the triggering mechanism could have been movement of the dam north of the dividing dam, as Dr Penman's text points out, 'due to the evidently very high phreatic surface and seepage of water through the dam'.

What is undoubtedly clear is that the contribution of the progressive failure (related to very low residual strength), probably associated with the existence of planes of weakness within the marl foundation, and non-dissipated high pore pressures (related to the external high loads) have been the main causes of the failure. Recent piezometric measurements carried out as part of the programme of closure of the impoundment, have shown a direct dependence of these high values of pore water pressures in the foundation on the variations of earthfill heights. In other words, the pore water pressures due to external loads had not dissipated even over a very prolonged period. This is due to the extremely low permeability, homogeneity and large thickness of the marl foundation. 